\title{
Putative fishery-induced changes in biomass and population size structures of demersal deep-sea fishes in ICES Sub-area VII, Northeast Atlantic Ocean
}

\author{
J. A. Godbold ${ }^{1,2}$, D. M. Bailey ${ }^{3}$, M. A. Collins ${ }^{4}$, J. D. M. Gordon ${ }^{5}$, W. A. Spallek ${ }^{6}$, and I. G. Priede ${ }^{1}$ \\ ${ }^{1}$ Oceanlab, University of Aberdeen, Newburgh, Aberdeenshire AB41 6AA, UK \\ ${ }^{2}$ National Oceanography Centre, Southampton, University of Southampton, Waterfront Campus, European Way, \\ SO14 3ZH, UK \\ ${ }^{3}$ Institute of Biodiversity, Animal Health and Comparative Medicine, University of Glasgow, Graham Kerr Building, \\ Glasgow G12 8QQ, UK \\ ${ }^{4}$ Government of South Georgia and the South Sandwich Islands, Government House, Port Stanley, Falkland Islands, \\ FlQQ 1ZZ, UK \\ ${ }^{5}$ Scottish Marine Institute, Scottish Association for Marine Science, Oban PA37 1QA, UK \\ ${ }^{6}$ Faculty of Earth Science and Environmental Management, University of Wroclaw, pl. Uniwersytecki 1, \\ 50-137 Wroclaw, Poland
}

Correspondence to: J. A. Godbold (j.a.godbold@soton.ac.uk)

Received: 17 July 2012 - Published in Biogeosciences Discuss.: 10 August 2012

Revised: 17 December 2012 - Accepted: 25 December 2012 - Published: 25 January 2013

\begin{abstract}
A time series from 1977-1989 and 2000-2002 of scientific trawl surveys in the Porcupine Seabight and adjacent abyssal plain of the NE Atlantic was analysed to assess changes in demersal fish biomass and length frequency. These two periods coincide with the onset of the commercial deep-water fishery in the late 1970s and the onset of the regulation of the fishery in the early 2000's, which allowed us to investigate changes in the relationship between total demersal fish biomass and depth between the pre- and post commercial fishing periods, as well as changes in the biomass $\left(\mathrm{kg} \mathrm{km}^{-2}\right)$ depth distribution and length frequency distribution of the most dominant fish species. Our results show a decline in total demersal fish biomass of $36 \%$ within the depth range of the commercial fishery $(<1500 \mathrm{~m})$. Whilst there were significant declines in target (e.g. Coryphaenoides rupestris decreased by $57 \%$ ) and non-target (e.g. C. guentheri and Antimora rostrata) species, not all species declined significantly. Changes in the overall length-frequency distribution were detected for 5 out of the 8 dominant species occupying depth ranges both within and outside the maximum depth for commercial trawling. This suggests that whilst there is evidence for likely fishery impacts on the
\end{abstract}

biomass distribution of the demersal fish population as a whole, species-specific impacts are highly variable. It is clear that changes in population structure can extend beyond the depth at which fishing takes place, highlighting the importance for also considering the indirect effects on deep-sea fish populations.

\section{Introduction}

Humans have used the oceans over millennia and significant technological advances now allow exploitation of fisheries' resources, hydrocarbons and minerals below a depth of $2000 \mathrm{~m}$ (Ramirez-Llodra et al., 2011). The environmental impacts of human activities on the deep-sea benthos are of increasing concern; of these, trawling appears to be the most significant, certainly in terms of the area affected. Recently it was shown that the annual spatial extent of seabed activity as a result of bottom trawling in areas of the NE Atlantic is significantly larger than the combined activities of laying submarine cables, waste disposal and oil and gas exploitation (Benn et al., 2010). Benthic fishing activities not 
only impact the target (and non-target) fish species, but also affect the abundance and diversity of the benthic epi- and infauna (e.g. Koslow et al., 2000; Gage et al., 2005; Clark and Koslow, 2007), which can have knock-on effects on the food web and for the functioning of the ecosystem (Watling and Norse, 1998; Hinz et al., 2009).

The continental slopes of the NE Atlantic are characterised by steep gradients, which represent areas of enhanced productivity and consequently support large and diverse demersal fish assemblages (Priede et al., 2010). As a result these areas have been the focus of many deep-water trawl fisheries since the 1970's. The onset of deep-water fisheries in the 1960's and 1970's coincided with the development of new and more robust fishing gear as strong declines in shallow-water fish stocks were observed in the North Atlantic (Koslow et al., 2000). The maximum depth that commercial fishing extends to is around $1600 \mathrm{~m}$ (Basson et al., 2002), although most fishing effort is focussed at depths around $1000 \mathrm{~m}$ where the commercially valuable species including Coryphaenoides rupestris (roundnose grenadier), Aphanopus carbo (black scabbardfish), Hoplosthethus atlanticus (orange roughy) and deep-water sharks are commonly found (Gordon et al., 2003; Priede et al., 2010). It has been shown that $71 \%$ of the demersal fish species inhabiting the continental margins of the Porcupine Seabight area are vulnerable to deep-water fisheries, as their depth ranges intersect the 500-1500 $\mathrm{m}$ trawling depth of the commercial fishing vessels (Priede et al., 2011).

Overfishing is one of the most serious conservation concerns in marine ecosystems (Worm et al., 2009) and understanding which species are most at risk remains a challenge, particularly in the deep-sea where species-specific information on ecology and life-history characteristics remains scarce. Available information for some deep-sea benthic fish species of commercial value including the orange roughy (H. atlanticus) and roundnose grenadier (C. rupestris) suggest that deep-water fish in general are very slow growing, long lived and have delayed maturity (Koslow et al., 2000; Morato et al., 2006). For example $C$. rupestris is thought to live up to $60 \mathrm{yr}$ and mature after 8-11 yr (Kelly et al., 1997), this low productivity makes deep-sea fish species highly vulnerable to fisheries and extremely difficult to conserve and manage (Merrett and Haedrich, 1997; Morato et al., 2006). Concerns over the sustainability of the largely unregulated deep-sea fisheries were brought about in the mid- to late 1990's by the International Council for the Exploration of the Sea (ICES) when a significant reduction in the catch per unit effort of the main target species, as well as severe depletion of local aggregations in the North Atlantic were detected (e.g. Gordon et al., 2003; Large et al., 2003; Large and Bergstad, 2005; Lorance et al., 2008). These trends were subsequently further confirmed by fisheries-independent longterm studies (e.g. Bailey et al., 2009) suggesting that commercial fisheries have significantly reduced the abundance of target and non-target species by $>50 \%$ since the onset of deep-water fishing. Whilst a decline in overall species abundances in response to exploitation is not surprising, little is known of what the long-term consequences of the fisheries are on population biomass and size-structure (but see Neat et al., 2010). Yet this information is of fundamental importance for the development of conservation and management strategies, as fisheries exploitation has already changed the mean trophic level of the fish community due to declines in larger, slow-growing species (Pauly et al., 1998; Hilborn et al., 2003).

Here we first estimate long-term trends in total biomass and size structure of the deep-water demersal fish community in the Porcupine Seabight and abyssal plain area of the NE Atlantic between the 1980s and early 2000s through comparison of fishery-independent trawl surveys carried out over these time periods. In this area of the NE Atlantic (ICES Subarea VII) the commercial deep-sea fishery developed in the early 1990s and has been subject to increasingly strict regulations since 2003. We first address the question of whether there is any evidence of changes in total biomass of the demersal fish community at depths $>800 \mathrm{~m}$ between the two periods (1980's and early 2000's) and further estimate changes in the total biomass of deep-water fish species for ICES Subarea VII and compare these to annual landings by the fishery (ICES, 2011). We then investigate any putative speciesspecific effects that the deep-water fishery may have had on the total biomass and length-frequency distribution of the 8 most dominant target and non-target demersal fish species.

\section{Materials and methods}

\subsection{The study area}

The deep-sea demersal fishes of the Porcupine Seabight and abyssal plain areas of the Northeast Atlantic Ocean (approx. $50^{\circ} \mathrm{N}, 13^{\circ} \mathrm{W}$ ) were surveyed by scientific bottom trawl from 1977 to 2002 (Fig. 1). For the present analysis we included data from trawls at depths ranging from 800 to $4865 \mathrm{~m}$ (=146 trawls), which is a subset of the full data set described by Bailey et al. (2009) and Priede et al. (2010, 2011). Trawls from depths $<800 \mathrm{~m}$ were excluded from the analysis as no upper slope trawling was carried out after 1989. In addition, eight trawls from 1997 were omitted from the analysis, because these trawls lacked 'time on bottom' data, which is required to calculate fish biomass $\left(\mathrm{kg} \mathrm{km}^{-2}\right)$ and abundance (ind. $\mathrm{km}^{-2}$ ) from trawl swept-area (calculated from time on bottom, vessel speed and door spread). The survey data were split into two distinct time periods, "early" period from 1977-1989 (95 trawls) and "late" period from 2000-2002 (51 trawls). The "early" period represents the state of the deep-sea fish assemblage before and during the initial development of the commercial fishery in this area, whilst the "late" period represents the time when the fishery was well established (Bailey et al., 2009; Priede et al., 2011). 
All the samples lie within ICES Sub-area VII (Divisions b, $\mathrm{c}, \mathrm{j}, \mathrm{k}$ ) corresponding to the area shown in Fig. 1 (boundary $48^{\circ} 00^{\prime} \mathrm{N}, 56^{\circ} 30^{\prime} \mathrm{N}, 9^{\circ} 00^{\prime} \mathrm{W}, 18^{\circ} 00^{\prime} \mathrm{W}$ ), for which the best available data on annual landings by the fishery are taken from ICES (2011).

\subsection{The sampling procedure}

A 45 -foot $(13.7 \mathrm{~m})$ semi-balloon otter trawl (OTSB, Marinovich Trawl Co., Biloxi, USA) was fished on a single warp (Merrett et al., 1991a). The width of seabed sampled was $8.6 \mathrm{~m}$ and haul duration varied between $60 \mathrm{~min}$ bottom contact time at around $800 \mathrm{~m}$ and $3 \mathrm{~h}$ bottom contact time on the abyssal plain with a tow speed of 2-2.5 knots. Variation in the bottom time with depth approximately equalised the catch sizes across the wide depth range sampled (Priede et al., 2010, 2011). Although this small trawl was very effective at catching a wide range of species, the limited herding action and low towing speed reduced the number of large and highly mobile species such as sharks and the black scabbardfish, Aphanopus carbo in the catch (Merrett et al., 1991a; Gordon et al., 1996). Length $(\mathrm{cm})$ and biomass (wet weight g) were determined for each individual caught. In the late period every fish captured was weighed to the nearest $1 \mathrm{~g}$ using on board heave-compensated digital scales (S-182, Pols, Iceland), which were calibrated at regular intervals during catch processing. In the early period this technology was not available, so the biomass ( $\mathrm{g}$ ) of individuals caught was calculated from length-weight relationships determined for individual species from sub-samples brought ashore supplemented with information from adjacent areas where appropriate (Supplement).

\subsection{Statistical analyses}

Change in the total demersal fish biomass $\left(\mathrm{kg} \mathrm{km}^{-2}\right)$ with depth between the early and the late period was analysed using an extended linear model with the variable "Depth" as an exponential variance covariate (varExp) to model the heteroscedasticity in the variance structure (Pinheiro and Bates, 2000). For eight of the most dominant species, in terms of total biomass $\left(\mathrm{kg} \mathrm{km}^{-2}\right)$, in the Porcupine Seabight and abyssal plain and for which there was sufficient data we investigated the species specific changes in biomass with depth and compared these between the early and late period.

Changes in individual species biomass with depth between the two periods were modelled using additive models with a Gaussian distribution, applied to $\log _{10}$-transformed data. We used $\log _{10}$ transformation to stabilise the variance and reduce the effect of large values. The latitude and longitude coordinates of the individual trawls were used to visually assess the effects of spatial autocorrelation using bubble plots (Pebesma, 2004). Spatial autocorrelation was detected for Coryphaenoides rupestris and the biomass data were analysed using an additive model with a Gaussian spatial corre- lation structure (corGauss) (Pinheiro and Bates, 2000). For Halosauropsis macrochir, data exploration indicated violation of homogeneity of variances, therefore requiring the use of varPower variance covariate structure that allows the residual spread to vary with respect to depth (Pinheiro and Bates, 2000; Zuur et al., 2009). In addition, for Synaphobranchus kaupii, data exploration also indicated violation of homogeneity of variances as a result of differences between sampling cruises. As the different cruises represent samples from the population about which we wish to make inferences we used a random effects model to model the variability caused by the factor "Cruise". For both the additive (GAM) and the additive mixed models (GAMM) the initial models included the factor "Period" (early or late) and a smoother over Depth (s(Depth)), which was compared to an alternative model including the factor (Period) and a s(Depth) for each period to identify the presence of a significant interaction. To estimate the optimal amount of smoothing for each smoother, we used cross-validation (Zuur et al., 2009) and alternative models were compared using the Aikaike information criterion (AIC). Once the optimal model was identified, the residuals were re-examined to ensure that model assumptions were met.

The Kolmogorov-Smirnoff (K-S) test was used to determine if the length-frequency distribution of 8 of the dominant demersal fish species differed significantly between the early and the late period. For Halosauropsis macrochir, in the early period, the individual lengths were measured as gnathoproctal length (GPL), whilst in the late period lengths were measured in pre-anal fin length (PAFL). As the GPL and PAFL in this species are very similar (O. A. Bergstad, personal communication, 2012), they were used directly for comparison of the length-frequency distribution between the two periods, rather than inter-conversion between the two data sets.

Analyses were conducted in $\mathrm{R}$ ( $\mathrm{R}$ Development Core Team 2008) using the "nlme" library for the extended linear model (Pinheiro et al., 2007), the "mgcv" library for the additive (mixed) models (Wood, 2007) and the "fishmethods" library for analysis of the length-frequency distributions and the Kolmogorov-Smirnoff Test (Nelson, 2010).

\subsection{GIS methods}

Charts of Sub-area VII were developed using the General Bathymetric Chart of the Oceans (GEBCO). The bathymetric grid was exported (GEBCO Grid Demonstrator v 2.12) to an ASCII file and converted to a raster dataset using ArcView 9.3. The data were projected onto Universal Transverse Mercator (UTM) based on the World Geodetic System (WGS) 1984 ellipsoid and ArcView 9.3 was then used to select the study area and extract it from the GEBCO raster dataset. The geographic coordinate system (GCS) was transformed onto cylindrical equal area projection in secant normal aspect, with longitude of the central meridian at $13.5^{\circ} \mathrm{W}$ and standard parallels at $51^{\circ} \mathrm{S}$ and $51^{\circ} \mathrm{N}$. During the transformation 


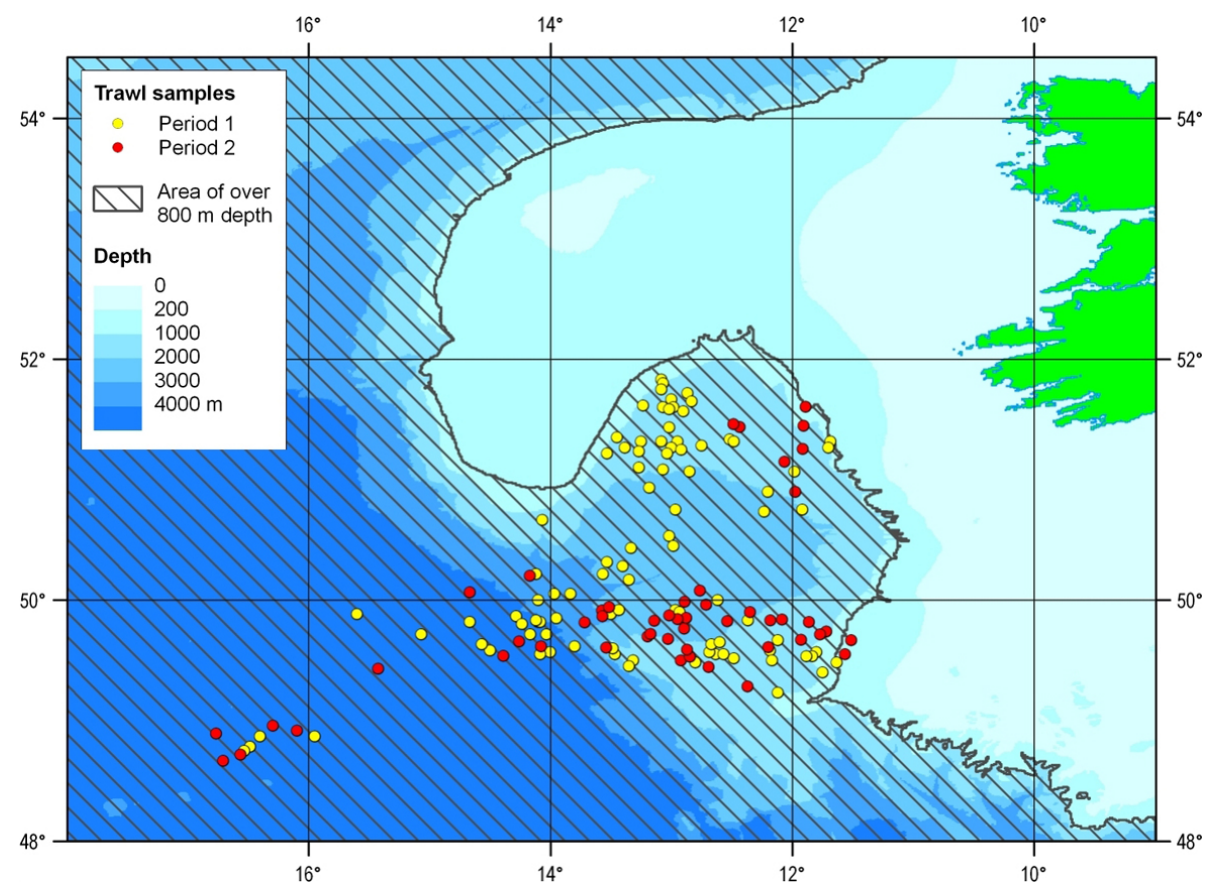

Fig. 1. Locations of the trawl stations. Period 1 (early period), pre-fishery years 1997-1989, period 2 (late period) during the commercial fishery years 2000-2002. $800 \mathrm{~m}$ indicates the minimum depth sampled in this study.

a new cell size $(734.215 \mathrm{~m})$ for the output raster dataset was automatically generated by ArcView, as optimized for the particular projection.

Fitted relationships for biomass as a function of depth were applied to GEBCO bathymetry. To predict the total demersal fish biomass across the entire Sub-area VII for both periods, linear functions were used (Eqs. 1 and 2):

Early period: $y=-0.2253 x+1351$,

Late period: $y=-0.1261 x+853.27$,

where $y$ is total biomass $\left(\mathrm{kg} \mathrm{km}^{-2}\right)$, and $x$ is depth (m).

Biomass of the roundnose grenadier (Coryphaenoides rupestris, the main target species) as a function of depth was found to be non-linear. Therefore, for the prediction of total biomass for both periods we estimated using segmented regression models.

Biomass values were calculated for each cell of the raster dataset with a depth $\geq 800 \mathrm{~m}$ and converted to total demersal fish biomass (in tonnes) by multiplying the mean biomass $\left(\mathrm{kg} \mathrm{km}^{-2}\right)$ resulting in ArcView 9.3 by area at depths $>800 \mathrm{~m}\left(\mathrm{~km}^{2}\right)$. Area in the raster dataset was determined by counting pixels and multiplying by the pixel area, which were derived from pixel size (O'Sulivan and Unwin, 2003).

\section{Results}

\subsection{Changes in total demersal fish biomass with depth and over time}

In the present analysis 93 demersal fish species were identified to occur at depths $>800 \mathrm{~m}$ in the Porcupine Seabight and the adjacent abyssal plain areas of the Northeast Atlantic. The results show a significant decline in total demersal fish biomass with depth in both periods (depth $\times$ period, L. ratio $=4.240$, d.f. $=1, p<0.05$, Fig. 2). At $1000 \mathrm{~m}$, within the depth zone of the commercial fishery, the results show that total biomass decreased from $1126 \mathrm{~kg} \mathrm{~km}^{-2}$ in the early period to $727 \mathrm{~kg} \mathrm{~km}^{-2}$ in the late period. On the abyssal plain ( $>4000 \mathrm{~m}$ depth) total biomass decreased from $<450 \mathrm{~kg} \mathrm{~km}^{-2}$ to $<349 \mathrm{~kg} \mathrm{~km}^{-2}$ in the early and late period respectively. Extrapolation to the entire ICES Sub-area VII (Fig. 3) would suggest that total fish biomass across the slope area decreased by $28 \%$ from $169792 \mathrm{t}$ in the early period to $122493 \mathrm{t}$ in the late period.

\subsection{Species specific changes in total biomass with depth and over time}

Although 93 demersal fish species were recorded, only the 8 species listed in Table 1 were encountered in sufficient frequency to model their spatial and temporal patterns of biomass effectively. Coryphaenoides rupestris, the main species targeted by the commercial fishery, showed a significant decline in biomass $\left(\log _{10} \mathrm{~kg} \mathrm{~km}^{-2}\right)$ across its entire 
Table 1. Summary results for the 8 most dominant species in terms of total biomass $\left(\mathrm{kg} \mathrm{km}^{-2}\right)$ at the Porcupine Seabight and abyssal plain. *Species biomass distributions were analysed using generalised additive mixed modelling (GAMM). Here the terms "Period1" refer the early period and "Period2" the late period of trawling. SE represents the Standard error and Edf is the estimated degrees of freedom for the smoothers obtained by cross-validation. $\mathrm{s}($ Depth) refers to a smoother for depth irrespective of trawling period and $\mathrm{s}($ Depth $)$ : Factor(Period2) denotes that there is a separate smoother for changes in biomass with depth in Period2.

\begin{tabular}{|c|c|c|c|c|c|c|c|c|c|}
\hline \multirow[b]{2}{*}{ Species } & & \multicolumn{4}{|c|}{ Biomass } & & \multicolumn{3}{|c|}{ Depth distribution } \\
\hline & & Estimate & SE & $\mathrm{t}$-value & $\mathrm{p}$-value & & Edf & $F$ & p-value \\
\hline $\begin{array}{l}\text { Synaphobranchus } \\
\text { kaupii* }\end{array}$ & Intercept & 1.45 & 0.095 & 15.71 & $<0.0001$ & $\mathrm{~s}$ (Depth) & 4.492 & 19.49 & $<0.0001$ \\
\hline $\begin{array}{l}\text { Halosauropsis } \\
\text { macrochir* }\end{array}$ & Intercept & 1.169 & 0.049 & 23.76 & $<0.0001$ & $\begin{array}{l}\mathrm{s} \text { (Depth) } \\
\mathrm{s}(\text { Depth }): \text { Factor(Period2) }\end{array}$ & $\begin{array}{l}4.184 \\
3.608\end{array}$ & $\begin{array}{r}9.803 \\
11.636\end{array}$ & $\begin{array}{l}<0.0001 \\
<0.0001\end{array}$ \\
\hline Coryphaenoides & Intercept & 1.44 & 0.059 & 24.504 & $<0.0001$ & s(Depth) & 4.988 & 14.603 & $<0.0001$ \\
\hline guentheri & Factor(Period2) & -0.102 & 0.53 & -1.949 & 0.055 & $\mathrm{~s}($ Depth $):$ Factor(Period2) & 1.5 & 5.934 & $<0.01$ \\
\hline $\begin{array}{l}\text { Coryphaenoides } \\
\text { rupestris* }\end{array}$ & $\begin{array}{l}\text { Intercept } \\
\text { Factor(Period2) }\end{array}$ & $\begin{array}{r}2.0241 \\
-0.367\end{array}$ & $\begin{array}{r}0.13 \\
0.178\end{array}$ & $\begin{array}{r}15.578 \\
-2.063\end{array}$ & $\begin{array}{r}<0.0001 \\
<0.05\end{array}$ & $\mathrm{~s}($ Depth $)$ & 3.909 & 4.425 & $<0.001$ \\
\hline $\begin{array}{l}\text { Coryphaenoides } \\
\text { armatus }\end{array}$ & Intercept & 2.94 & 0.619 & 4.747 & $<0.0001$ & $\begin{array}{l}\text { s(Depth) : Factor(Period } 1) \\
\text { s(Depth) : Factor(Period2) }\end{array}$ & $\begin{array}{l}5.563 \\
3.608\end{array}$ & $\begin{array}{r}4.557 \\
11.636\end{array}$ & $\begin{array}{r}<0.001 \\
<0.0001\end{array}$ \\
\hline Nezumia aequalis & Intercept & 0.77 & 0.057 & 13.53 & $<0.0001$ & $\begin{array}{l}\mathrm{s} \text { (Depth): Factor(Period } 1) \\
\mathrm{s}(\text { Depth }): \text { Factor(Period2) }\end{array}$ & $\begin{array}{l}7.634 \\
6.081\end{array}$ & $\begin{array}{r}15.78 \\
5.05\end{array}$ & $\begin{array}{r}<0.0001 \\
<0.001\end{array}$ \\
\hline Antimora rostrata & Intercept & 1.195 & 0.072 & 16.65 & $<0.0001$ & $\begin{array}{l}\mathrm{s} \text { (Depth) } \\
\mathrm{s} \text { (Depth): Factor(Period2) }\end{array}$ & $\begin{array}{r}5.808 \\
2.53\end{array}$ & $\begin{array}{r}36.829 \\
6.811\end{array}$ & $\begin{array}{r}<0.0001 \\
<0.001\end{array}$ \\
\hline Lepidion eques & Intercept & 1.428 & 0.57 & 24.89 & $<0.0001$ & $\mathrm{~s}($ Depth $)$ & 3.066 & 39.41 & $<0.0001$ \\
\hline
\end{tabular}

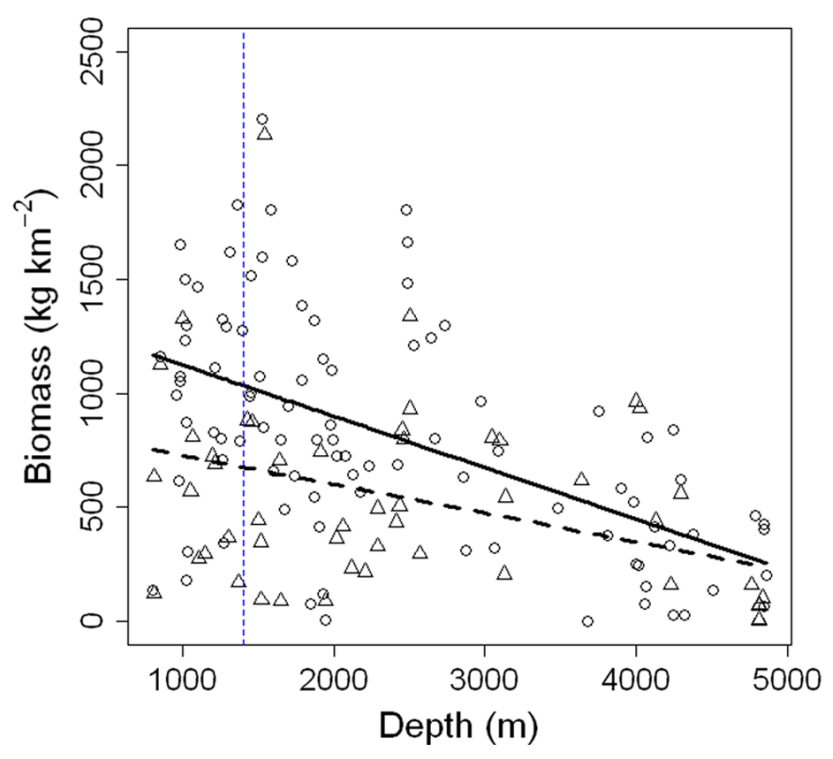

Fig. 2. Changes in total demersal fish biomass $\left(\mathrm{kg} \mathrm{km}^{-2}\right)$ with depth in the Porcupine Seabight and abyssal plain area of the Northeast Atlantic Ocean between the early (1977-1989, circles) and late (2000-2002, triangles) trawling periods. Model predictions for changes in total biomass with depth in the early (solid line) and late (dashed line) period. The vertical dashed line represents the approximate maximum depth of commercial fishing in this area.

depth range, 800-1932 m, between the two periods (Table 1, Fig. 4). The peak biomass is at $1500 \mathrm{~m}$ where the biomass decreased from 386 to $166 \mathrm{~kg} \mathrm{~km}^{-2}$. Extrapolating over the entire ICES Sub-area VII (Fig. 5), the predicted total biomass was $7525 \mathrm{t}$ in the early period and $3232 \mathrm{t}$ in the late period, a decrease of $57 \%$ of the initial biomass.

Several non-target species also showed changes in biomass between the early and late periods. The biomass $\left(\log _{10} \mathrm{~kg} \mathrm{~km}^{-2}\right)$ of Coryphaenoides guentheri, (depth range $1200-2875 \mathrm{~m}$ ) declined significantly at depths $<2000 \mathrm{~m}$ (Table 1, Fig. 4) but there was no difference at its depth of maximum biomass ca. $2500 \mathrm{~m}$. The deeper-living Coryphaenoides armatus (depth range 2016-4865 m), increased in biomass in the late period at $3000-4000 \mathrm{~m}$ depth (Fig. 4). Nezumia aequalis (depth range 800-1650 m) showed a small decrease in biomass over the shallower part of its depth range (Fig. 4), but biomass was higher in the late period than the early period at depths greater than ca. $1400 \mathrm{~m}$. In contrast to $C$. guentheri and $C$. armatus, Antimora rostrata (depth range 853-2970 m) showed a significant decrease in biomass between the early and later period at depths greater than $1500 \mathrm{~m}$. At its depth of maximum biomass $(2500 \mathrm{~m})$ the biomass decreased from 920 to $148 \mathrm{~kg} \mathrm{~km}^{-2}$ (Fig. 4).

For Synaphobranchus kaupii (depth range 800-2500 m), Halosauropsis macrochir (1440-3485 m,) and Lepidion eques (depth range 506-2420 m), no differences were found in the total biomass between the two periods (Table 1, Fig. 4).

\subsection{Changes in the length-frequency distribution}

The size structure (Fig. 6a) for S. kaupii did not significantly change in the depth ranges from 800-1300 (K-S test, $D=0.169, p=0.280)$ and $1300-1800(\mathrm{~K}-\mathrm{S}$ test, $D=0.113$, $p=0.500)$. The median standard length of individuals at 800 to $1300 \mathrm{~m}$ depth was $20 \mathrm{~cm}$ in the early and $22 \mathrm{~cm}$ in the late period. At 1300-1800 $\mathrm{m}$ depth the median standard length reduced from $34.5 \mathrm{~cm}$ to $33.5 \mathrm{~cm}$ in the early and late period 


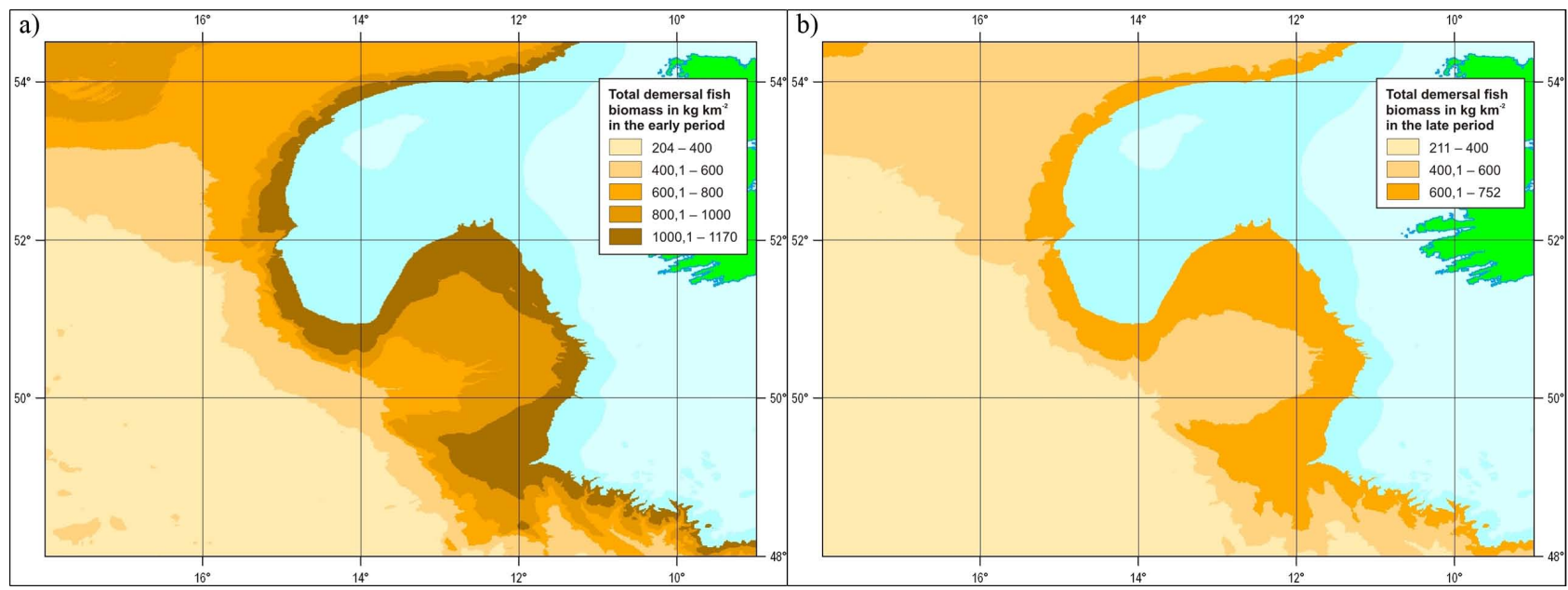

Fig. 3. The GIS predicted model of spatial distribution of total fish biomass $\left(\mathrm{kg} \mathrm{km}^{-2}\right)$ in ICES Sub-area VII (Divisions b, $\mathrm{c}, \mathrm{j}$, $\left.\mathrm{k}\right)$ based on the regression lines in Fig. 2 for (a) the early (1977-1989) and (b) the late (2000-2002) period.

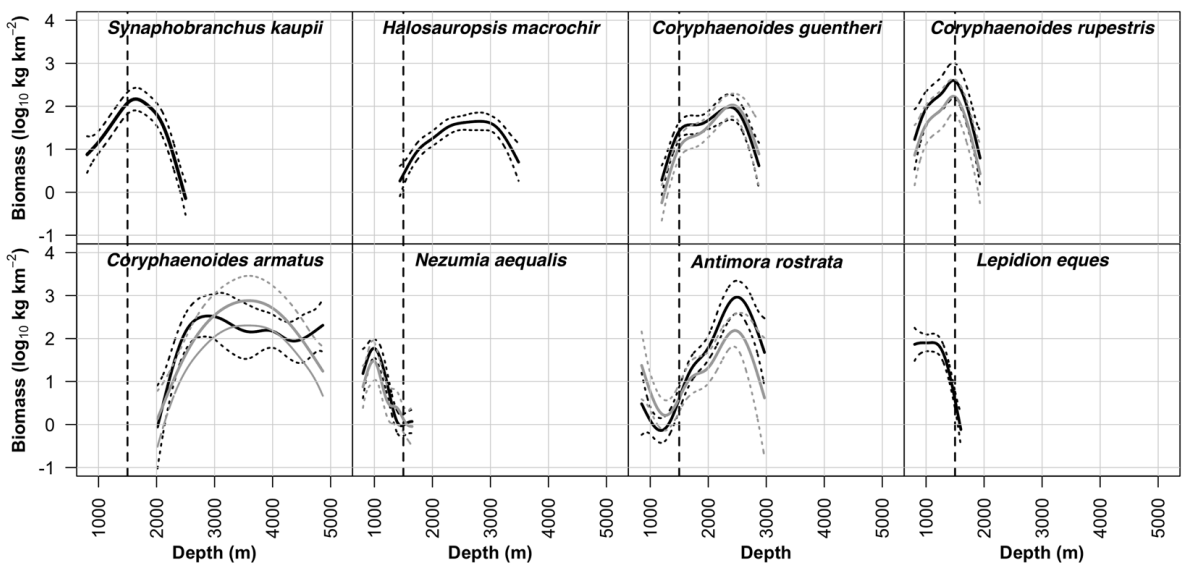

Fig. 4. Biomass trends $\left(\log _{10} \mathrm{~kg} \mathrm{~km}^{2}\right)$ for the eight most dominant species in terms of biomass in the Porcupine Seabight and Abyssal Plain. Model predictions (solid lines) and $95 \%$ confidence intervals (dashed lines) are shown for changes in total biomass for individual species with depth in the early (black) and late (grey) period.

respectively, with a slight increase in the frequency of larger individuals $(>40 \mathrm{~cm})$ in the late period. At depths between $1800-2500 \mathrm{~m}$ there was a significant shift in the population to larger individuals from the early to late period (K-S test, $D=0.298, p<0.05$ ), with the median standard length increasing from 41.5 to $45.5 \mathrm{~cm}$ respectively.

The size structure of the H. macrochir (Fig. 6b) population increased significantly to larger pre-anal fin lengths in the late period (K-S test, $D=0.608, p=0.01$ ), with an increase in the median pre-anal fin length from 20 to $23.5 \mathrm{~cm}$ between the two periods.

The cumulative length-frequency distribution of C. guentheri did not change significantly between the early and late period irrespective of depth bin $(1200-1800 \mathrm{~m}$ : K-S test, $D=0.164, p=0.58 ; 1800-2400 \mathrm{~m}$ : K-S test, $D=0.99$, $p=0.15 ; 2400-2875 \mathrm{~m}$ : K-S test, $D=0.019, p=0.88$, Fig. 6c). Whilst the median head length did not vary between time periods, it did increase with depth (1200-1800 m: early vs. late, 4 and $4.45 \mathrm{~cm} ; 1800-2400$ : early vs. late, 5.8 and $5.8 \mathrm{~cm}$; 2400-2875: early vs. late, 6.1 and $6.1 \mathrm{~cm}$ ).

Similarly, the cumulative length-frequency distribution of C. rupestris also did not change significantly between the early and late period irrespective of depth bin (800-1300 m: K-S test, $D=0.241, p=0.160 ; 1300-1900 \mathrm{~m}$ : K-S test, $D=0.06, p=0.750)$. The results suggest that in the $800-1300 \mathrm{~m}$ depth interval there was an increase in the number of large individuals in the late period, shifting the median head length from $8 \mathrm{~cm}$ in the early to $9.7 \mathrm{~cm}$ in the late period (Fig. 6d).

C. armatus, however, showed a significant change in population size structure across the whole of its depth range $\quad(2000-3000 \mathrm{~m}: \quad \mathrm{K}-\mathrm{S}$ test, $\quad D=0.240, \quad p<0.05$; $3000-4000 \mathrm{~m}: \quad D=0.273, \quad p=0.07 ; \quad 4000-5000 \mathrm{~m}$ : $D=0.327, p<0.05$ ). Between the early and late period 


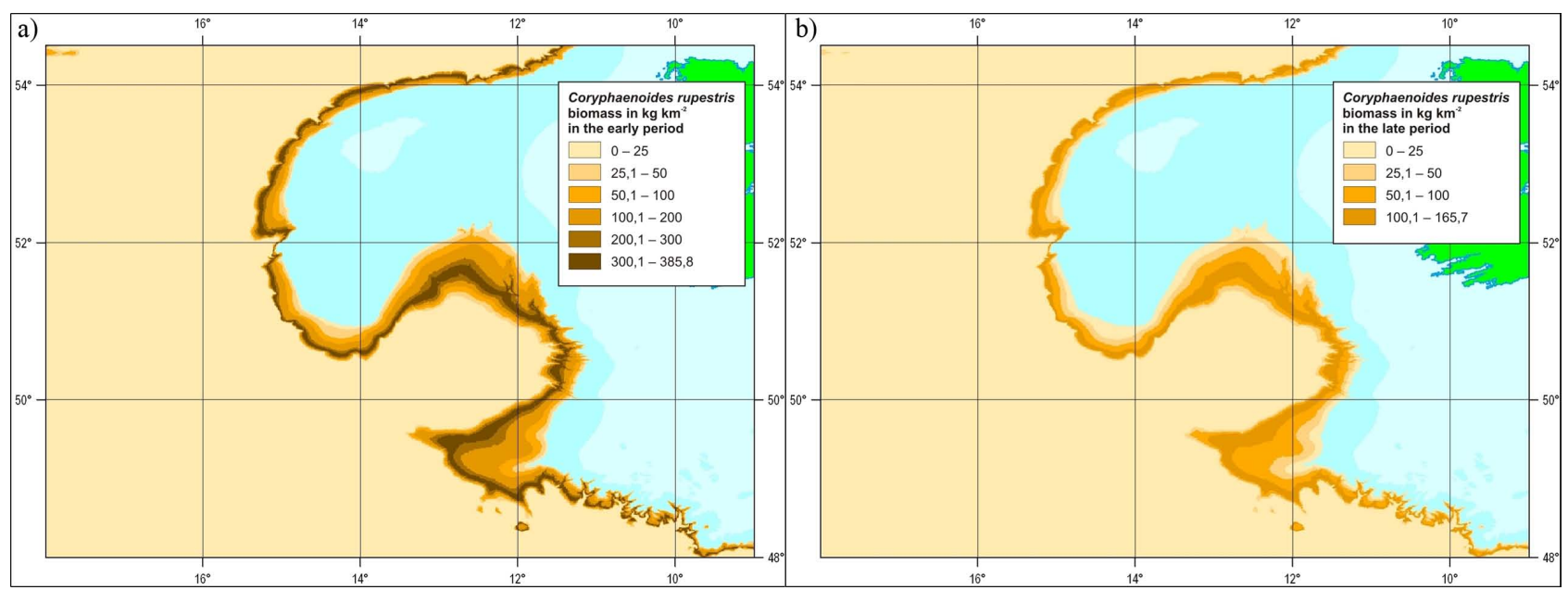

Fig. 5. The GIS predicted model of spatial distribution for biomass $\left(\mathrm{kg} \mathrm{km}^{-2}\right)$ of the main target commercial fish species, roundnose grenadier Coryphaenoides rupestris in ICES Sub-area VII (Divisions b, c, j, k) based on the fitted models in Fig. 4b. for (a) the early (1977-1989) and (b) the late (2000-2002) period.

at all depths the median head length shifted to a smaller size, 7.6 to $7.2 \mathrm{~cm}, 9.3$ to $8.6 \mathrm{~cm}$ and 13 to $11.5 \mathrm{~cm}$ with increasing depth (Fig. 6e). In addition, the results show that overall the head length of $C$. armatus individuals increased with depth, irrespective of time period.

The $N$. aequalis population showed a significant change in size-structure across its depth range between the early and the late period (800-1650: K-S test, $D=0.162, p<0.05$ ). This trend appears to be largely driven by an increase in the number of individuals with a head length between 2 and $3 \mathrm{~cm}$ in the late period (Fig. 6f). The median head length between the two periods increased slightly from 3.5 to $3.7 \mathrm{~cm}$.

No significant change in the cumulative size-frequency distribution was found for $A$. rostrata (Fig. $6 \mathrm{~g}$ ) across its depth range (800-1916: K-S test, $D=0.115, p=0.85$; 1916-3000 m: K-S test, $D=0.165, p=0.15)$. At the shallow end of its depth range, the median standard length of A. rostrata decreased from 18.5 in the early to $16.3 \mathrm{~cm}$ in the late period, with no difference in median standard length between periods at the deep end of its depth rage (early vs. late 46.1 and $47 \mathrm{~cm}$ ).

The population size structure of $L$. eques was also found to change significantly between the two periods (800-1100: K-S test, $D=0.26, p<0.05$ ), and the median standard length shifted from $24.2 \mathrm{~cm}$ in the early to $20.2 \mathrm{~cm}$ in the late period (Fig. 6h).

\section{Discussion}

The present analysis shows that there was major decline in demersal fish biomass over a large area of the bathyal slopes of ICES Sub-area VII, the Porcupine Seabight and adjacent areas, following the onset of a commercial fishery around 1990. We estimate that the fish biomass in the area decreased by $47300 \mathrm{t}$ so that biomass remaining in the late period was $72 \%$ of the biomass present in the early period. Over the decade, 1992-2001 the fishery reported mean annual landings of $1566 \mathrm{t}$ of orange roughy (Hoplostethus atlanticus) $1304 \mathrm{t}$ of roundnose grenadier (C. rupestris) and $520 \mathrm{t}$ of black scabbard fish (Aphanopus carbo) (data from ICES, 2010). Bailey et al. (2009) showed a significant decrease in terms of demersal fish abundance could be detected down to $2500 \mathrm{~m}$, suggesting that the impact of the fishery extended beyond the maximum depth of commercial fishing $(\sim 1500 \mathrm{~m})$. Similarly in the present study we detected a significant decline in the total demersal fish biomass, particularly at depths $800-2000 \mathrm{~m}$.

For the commercially targeted species $C$. rupestris we estimate that the biomass decreased from $7525 \mathrm{t}$ in period 1 to $3232 \mathrm{t}$ in the late period (Fig. 5). ICES (2011) made an exploratory assessment of total biomass of $C$. rupestris in ICES Sub-areas Vb,VI, and VII based on landings and landings per unit effort data indicating decrease in biomass from ca. $140000 \mathrm{t}$ in 1988 to $55000 \mathrm{t}$ in 2001 . The landings from Sub-area VII comprise on average 0.09 of the total landings in Sub-areas Vb, VI and VII. Assuming stock biomass follows the same ratio this implies that the biomass in Subarea VII was approximately $12600 \mathrm{t}$ in 1988 and $4950 \mathrm{t}$ in 2001, which is 1.67 and 1.53 times higher than our estimates. Given the high probability that a significant proportion of the fish population escapes the OTSB net (Merrett et al., 1991a, b; Gordon et al., 1996) these results are in remarkably close agreement, and could be reconciled by assuming a $60 \%$ trawl capture efficiency for the OTSB. We found no significant change in length-frequency distribution of $C$. rupestris between the early and late periods, although at the shallower end of its depth range the results suggest higher frequencies of larger individuals ( $>8 \mathrm{~cm}$ head length) 

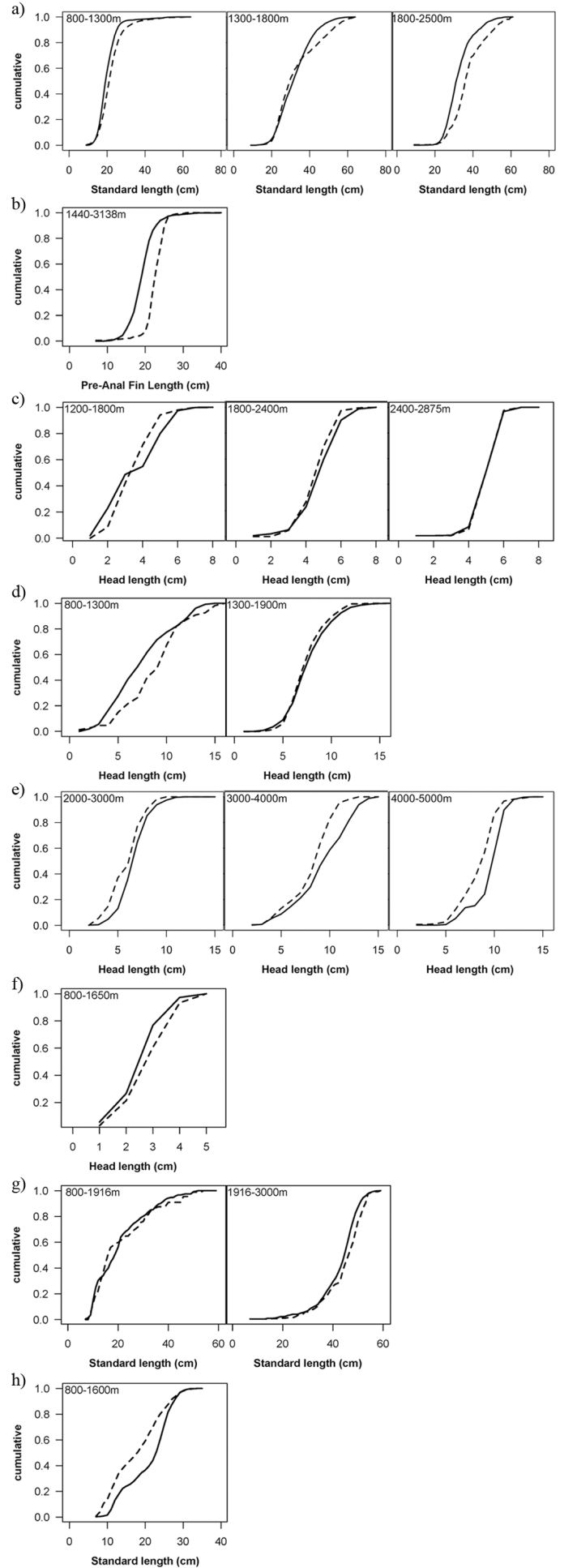

Fig. 6. Cumulative percentage length distribution of (a) Synaphobranchus kaupii, (b) Halosauropsis macrochir, (c) Corpyphaenoides guentheri, (d) Coryphaenoides rupestris, (e) Coryphaenoides armatus, (f) Nezumia aequalis, (g) Antimora rostrata and (h) Lepidion eques for different depth strata. Solid line - early period $=1977-1989$, dashed line - - late period $=2000-2002$. in the early 2000s. This contradicts the findings of ICES (2011) that there has been a general decline in lengths of fish landed since 1990. However interpretation of the true population size structure from commercial fishery data is complicated by the high levels of discarding small fishes (Lorance et al., 2001) in addition to changes in discarding practices, with increasing numbers of smaller fish being accepted by the market as the fishery progressed. The overall pattern of the impact of the fishery is that biomass of $C$. rupestris has decreased by $57 \%$, compared with a $41 \%$ decrease in numbers reported by Priede et al. (2011).

The depth range of Coryphaenoides guentheri, $(1200-2875 \mathrm{~m})$ is predominantly deeper than the $1500 \mathrm{~m}$ maximum depth of the fishery. It is interesting to observe, therefore, that both abundance (Bailey et al., 2009; Priede et al., 2011) and biomass (Fig. 4) of this species decrease at the shallow end of the depth range between the early and late period, suggesting that individuals further up the slope have likely been affected by the fishery. The fishery does not seem to have affected $C$. guentheri further down the slope, where biomass is the same and highest for both periods. These trends are consistent with the length-frequency analysis in the present study and previous analyses of trawl data from this region, which revealed a significant increase in body size of $C$. guentheri with depth (Collins et al., 2005) suggesting that this species moves deeper with increasing age.

Coryphaenoides armatus, the abyssal grenadier, has an upper depth limit of $2016 \mathrm{~m}$ and therefore the entire population lives beyond the limit of the fishery and presumably cannot be affected directly. Nevertheless the results show a significant increase in biomass at continental rise depths (3000 to $4000 \mathrm{~m}$ ) (Fig. 6), which is also reflected in a similar increase in abundance at these depths (Priede et al., 2011). However, the increase in total biomass of $C$. armatus across its depth range appears to be a result of an increase in frequency of smaller individuals (Fig. 6e) in comparison to the early period. This may be the result of natural fluctuations in recruitment episodes that have occurred independently of any effect of the fishery (Bailey et al., 2006), although the possibility of a cascade effect (Myers et al., 2007) resulting from removal of fishes in shallower areas cannot be excluded. As this species is a facultative scavenger it is possible that changes in carrion availability over the study period have been important. However, no general effect on scavenger abundance was detected by Bailey et al. (2009) when compared to species that are not known to feed on carrion.

A large proportion of the depth range of Nezumia aequalis straddles the depth zone of commercial fishery operations so it is clearly a vulnerable species that has significantly decreased in both abundance (Priede et al., 2011) and biomass, although the decrease in abundance is greater than the decrease in biomass. As the population size structure of $N$. aequalis shifted to larger individuals in the late period, the results likely suggest density dependent compensatory growth in the individuals that escape the impact of the fishery (Rose 
et al., 2001). At depths greater than $1500 \mathrm{~m}$ there is no change in abundance but there is an increase in biomass, further suggesting a general increase in size of this species over time.

The pattern of change in biomass of Antimora rostrata exactly mirrors the observed changes in abundance of this species reported by Priede et al. (2011), where highest abundance and biomass were observed at depths greater than $1500 \mathrm{~m}$ and a paradoxical increase in abundance and biomass at shallower depths $(<1000 \mathrm{~m})$, which are directly impacted by the fishery. A. rostrata is a conspicuous scavenging species often seen at baited cameras deployed at shallower depths (Priede et al., 1994) so it may benefit from feeding on discards or damaged fauna within the fishery area. Similar to the size distribution observed for $C$. rupestris the results show an increase in the length-frequency distribution of $A$. rostrata, suggesting that this species moves to greater depths with increasing age. The decrease in biomass at depths $>1500$ in the late period may reflect variability in recruitment patterns, but at present there is insufficient data on this species to allow identification of the mechanisms underpinning the observed changes in biomass.

The eel Synaphobranchus kaupii is the most abundant fish species on the upper slope of the NE Atlantic. It is metabolically active (Bailey et al., 2005) and regularly appears in large numbers at baits in different habitats (Priede et al., 1994; Heger et al., 2007). Bailey et al. (2009) and Priede et al. (2011) showed that the abundance of this non-target species was highly significantly reduced from $4099 \mathrm{~km}^{-2}$ in the early to $2110 \mathrm{~km}^{-2}$ in the late period. It is therefore somewhat surprising that there has been no corresponding change in biomass; biomass appears to have remained constant. This implies there must have been a shift in size frequency distribution towards larger individuals. Inspecting Fig. 6a the only statistically significant change in size frequency distribution is in the depth range $1800-2500 \mathrm{~m}$, however at $800-1300 \mathrm{~m}$ there is a small increase in median length and at $1300-1800 \mathrm{~m}$ there is an interesting second mode in the late period of individuals larger than $40 \mathrm{~cm}$. The composition of samples of $S$. kaupii can be numerically greatly influenced by the presence of many tiny individuals weighing just a few $\mathrm{g}$ each and conversely a few large individuals weighing over $1 \mathrm{~kg}$ can influence biomass. In addition, S. kaupii are highly mobile species, thus the significant reduction in abundance observed in Bailey et al. (2009) may have reduced intraspecific competition for food resources increasing growth rates of individuals at depth. Changes such as these may be sufficient to account for the apparent compensation in biomass of $S$. kaupii in the face of reduction in population size.

Halosauropsis macrochir, although occurring predominantly below the depth zone of the fishery has been shown to undergo a significant reduction in abundance between the early and late period (Bailey et al., 2009; Priede et al., 2011). The present results show that there has been no corresponding change in biomass (Fig. 4), but the shift in the lengthfrequency distribution of this species to larger size classes in the late period may suggest that this species is also exhibiting density dependent increases in growth as a result of reduced intraspecific competition.

Bailey et al. (2009) found that the fishery did not negatively impact Lepidion eques, despite its depth range coinciding almost entirely with the depth zone of the commercial fishery. It was later also shown that $L$. eques abundance increased in the late period (Priede et al., 2011). Although in the present study we also detect no change in biomass between the early and late period, the results do show a change in the size structure of the L. equalis population, as the standard length reduced significantly in the late period.

\subsection{Conclusions}

Reductions in fish biomass have occurred within this region of the NE Atlantic and in the only case where a comparison can be made, our estimates of this reduction are in agreement with those of fishery scientists. Our study includes a wide range of target and non-target species and demonstrates that reductions in biomass are common across this fish assemblage and extend outside the fished area itself. However, responses are strongly species-specific, likely reflecting differences in life-history characteristics, changes in population dynamics as a result of competitive release and compensatory growth. The abyssal grenadier (C. armatus) in particular exhibited significant increases in biomass, which may have occurred as a result of changes in the food supply and/or recruitment. Understanding of the observed patterns in biomass in response to the deep-sea fishery thus requires further detailed understanding of the behavior and ecology of individual species.

From 2003, fishing has been strongly regulated by the EU and limited by total allowable catches (TACs), which has resulted in reduction of reported landings to a mean of $286 \mathrm{t} \mathrm{yr}^{-1}$ in 2005-2007 and a mean of $53 \mathrm{t}$ for the years 2008-2011 (ICES, 2012). It is likely, therefore, that the impact of the fishery has been greatly diminished in recent years, as has been suggested by Neat and Burns (2010) from a survey area further north within ICES Division VIa. Future surveys will be vital in order to ascertain a reversal of the trends observed for some of the impacted species identified here.

\section{Supplementary material related to this article is available online at: http://www.biogeosciences.net/10/ 529/2013/bg-10-529-2013-supplement.pdf.}


Acknowledgements. This work was supported by a series of NERC grants to the principal investigators including NE/C512961/1. The results of the early joint SAMS and IOS surveys were digitized with support from EU MAST Contract MAS2-CT920033 1993-1995, and data analyses was supported by EU FP7 Projects HERMES and HERMIONE. We thank Alain Zuur from Highland Statistics Ltd. for advice with the statistical analyses and Odd Aksel Bergstad for valuable comments that helped to improve the manuscript. We thank the ships' companies of the RRS Challenger and RRS Discovery.

Edited by: R. Serrão Santos

\section{References}

Bailey, D. M., Genard, B., Collins, M. A., Rees, F., Unsworth, S. K., Battle, E. J. V., Bagley, P. M., Jamieson, A. J., and Priede, I. G.: High swimming and metabolic activity in the deep-sea eel Synaphobranchus kaupii revealed by integrated in situ and in vitro measurements, Physiol. Biochem. Zool., 78, 335-346, 2005.

Bailey, D. M., Ruhl, H. A., and Smith Jr., K. L.: Long-term change in benthopelagic fish abundance in the abyssal N.E. Pacific Ocean, Ecology, 87, 549-555, 2006.

Bailey, D. M., Collins, M. A, Gordon, J. D. M, Zuur, A. F., and Priede, I. G.: Long-term changes in deep-water fish populations in the northeast Atlantic: a deeper reaching effect of fisheries?, P. R. Soc. B, 276, 1965-1969, 2009.

Basson, M., Gordon, J. D. M., Large, P., Lorance, P., Pope, J., and Rackham, B.: The Effects of Fishing on Deep-water Fish Species to the West of Britain, JNCC Report No. 324, 1-150, 2002.

Benn, A., Weaver, P. P., Billett, D. S. M., van den Hove, S., Murdock, A. P., Doneghan, G. B., and Le Bas, T.: Human activities on the deep seafloor in the North East Atlantic: an assessment of spatial extent, PLoS ONE, 5, e12730, doi:10.1371/journal.pone.0012730, 2010.

Clark, M. R. and Koslow, J. A.: Impacts of fishing on seamounts, in: Seamounts: ecology, fisheries and conservation, edited by: Pitcher, T. J., Hart, P. J. B., Morato, T., Santos, R., and Clark, M., Blackwell Fisheries and Aquatic Resources Series 12, Blackwell Scientific, Oxforrd, 413-441, 2007.

Collins, M. A., Bailey, D. M., Ruxton, G. D., and Priede, I. G.: Trends in body size across an environmental gradient: A differential response in scavenging and non-scavenging demersal deep-sea fish, P. R. Soc. B, 272, 2051-2057, 2005.

Gage, J. D., Roberts, J. M., Hartley, J. R., and Humphery, J. D.: Potential impacts of deep-sea trawling on the benthic ecosystem along the Northern European continental margin: A review, in: Benthic habitats and the effects of fishing, edited by: Barnes, B. W. and Thomas, J. P., Am. Fish. S. S., 41, 503-517, 2005.

Gordon, J. D., Merrett, N. R., Bergstad, O. A., and Swan, S. C.: A comparison of the deep-water demersal fish assemblages of the Rockhall Trough and Porcupine Seabight, eastern North Atlantic: Continental slope to rise, J. Fish Biol., 49, Suppl. A, $217-$ 238, 1996

Gordon, J. D. M., Bergstad, O. A., Figueiredo, I., and Menezes, G.: Deep-water fisheries of the Northeast Atlantic: I. Description and Current Trends, J. Northw. Atl. Fish. Sci., 31, 137-150, 2003.

Heger, A., King, N. J., Wigham, B. D., Jamieson, A. J., Bagley, P. M., Allan, L., Pfannekuche, O., and Priede, I. G.: Benthic bi- oluminescence in the bathyal North East Atlantic: luminescent responses of Vargula norvegica (Ostracoda: Myodocopida) to predation by the deep-water eel (Synaphobranchus kaupii), Mar. Biol., 4, 1471-1478, 2007.

Hilborn, R., Branch, T. A., Ernst, B., Magnusson, A., Minte-Vera, C. V., Scheuerell, M. D., and Valero, J. L.: State of the world's fisheries, Annu. Rev. Env. Resour., 28, 359-399, 2003.

Hinz, H., Prieto, V., and Kaiser, M. J.: Trawl disturbance on benthic communities: chronic effects and experimental predictions, Ecol. Appl., 19, 761-773, 2009.

ICES: Report of the Working Group on the Biology and Assessment of Deep-sea Fisheries Resources (WGDEEP), Denmark ICES document CM 2010/ACOM: 17, 616 pp., 2010.

ICES: Report of the Working Group on the Biology and Assessment of Deep-sea Fisheries Resources (WGDEEP), Denmark ICES document CM 2011/ACOM: 17, 2011.

ICES: Report of the Working Group on the Biology and Assessment of Deep-sea Fisheries Resources (WGDEEP), Denmark ICES document CM 2012/ACOM: 17, 2012.

Kelly, C. J., Connolly, P. L., and Bracken, J. J.: Age estimation, growth, maturity and distribution of the roundnose grenadier from the Rockall trough, J. Fish Biol., 50, 1-17, 1997.

Koslow, J. A., Boehlert, G. W., Gordon, J. D. M., Haedrich, R. L., Lorance, P., and Parin, N.: Continental slope and deep-sea fisheries: implications for a fragile ecosystem, ICES J. Mar. Sci., 57, 548-557, 2000.

Large, P. A. and Bergstad, O. A.: Deepwater fish resources in the northeast Atlantic: fisheries, state of knowledge on biology and ecology, and recent developments in stock assessment and management, in: Deep Sea 2003: Conference on the Governance and Management of Deep-sea Fisheries Part 1, edited by: Shotton, R., 149-161 Conference reports, Queenstown, New Zealand, 15 December 2003, FAO Fisheries Proceedings, No. 3/1. Rome, FAO, 718 pp., 2005.

Large, P. A., Hammer, C., Bergstad, O. A., Gordon, J. D. M., and Lorance, P.: Deep-water Fisheries of the Northeast Atlantic: II Assessment and Management Approaches, J. Northw. Atl. Fish. Sci., 31, 151-163, 2003.

Lorance, P., Dupouy, H., and Allain, V.: Assessment of the roundnose grenadier (Coryphaenoides rupestris) stock in the Rockall Trough and neighbouring areas (ICES Sub-areas V-VII), Fish. Res., 51, 151-163, 2001

Lorance P., Bergstad, O. A., Large, P. A., and Gordon, J. D. M.: Grenadiers in the North East Atlantic - distribution, biology, fisheries and their impacts, and developments in stock assessment and management, Am. Fish. S. S., 63, 365-397, 2008.

Merrett, N. R. and Haedrich, R. L.: Deep-Sea Demersal Fish and Fisheries, Chapman \& Hall, London, 282 pp., 1997.

Merrett, N. R., Gordon, J. D. M., Stehman, M., and Haedrich, R. L.: Deep demersal fish assemblage structure in the Porcupine Seabight (eastern North Atlantic): slope sampling by three different trawls compared, J. Mar. Biol. Assoc. UK, 71, 329-358, 1991a.

Merrett, N. R., Haedrich, R. L., Gordon, J. D. M., and Stehmann, M.: Deep demersal fish assemblage strictire in the Porcupine Seabight (eastern North-Atlantic) - results of single warp trawling at lower slope to abyssal soundings, J. Mar. Biol. Assoc. UK, 71, 359-373, 1991b. 
Morato, T., Watson, R., Pitcher, T. J., and Pauly, D.: Fishing down the deep, Fish Fish, 7, 24-34, 2006.

Myers, R. A., Baum, J. K., Shepherd, T. D., Powers, S. P., and Peterson, C. H.: Cascading effects of the loss of apex predatory sharks from a coastal ocean, Science, 315, 1846-50, 2007.

Neat, F. and Burns, F.: Stable abundance, but changing size structure in grenadier fishes (Macrouridae) over a decade (1998-2008) in which deep-water fisheries became regulated, Deep-Sea Res. I, 57, 434-440, 2010.

Nelson, G. A.: Package "fishmethods", Fisheries Methods and Models in R, http://cran.r-project.org/web/packages/ fishmethods/fishmethods.pdf 2010.

O'Sulivan, D. and Unwin, D.: Geographic information analysis, Wiley, Hoboken, NJ, 2003.

Pauly, D., Christensen, V., Dalsgaard, J., Froese, R., and Torres, F.: Fishing down marine food webs, Science, 279, 860-863, 1998.

Parker, S. J., Penney, A. J., and Clark, M. R.: Detection criteria for managing trawl impacts on vulnerable marine ecosystems in high seas fisheries of the South Pacific Ocean, Mar. Ecol.-Progr. Ser., 397, 309-317, 2009.

Pebesma, E. J.: Multivariable geostatistics in S: the gstats package, Comp. Geosci., 30, 683-691, 2004

Pinheiro, J. C. and Bates, D. M.: Mixed-effects models in S and S-Plus, Springer Verlag, New York, LLC, 528 pp., 2000.

Pinheiro, J., Bates, D., DebRoy, S., and Sarkar, D.: Package "nlme". Linear and Nonlinear Mixed Effects Models, version 3.1-86, http://cran.r-project.org/web/packages/nlme/nlme.pdf, 2007.

Priede, I. G., Bagley, P. M., Smith, A., Creasey, S., and Merrett, N. R.: Scavenging deep demersal fishes of the Porcupine Seabight,(NE Atlantic Ocean); observations by baited camera, trap and trawl, J. Mar. Biol. Assoc. UK, 74, 481-498, 1994.

Priede, I. G., Godbold, J. A., King, N. J., Collins, M. A., Bailey, D. M., and Gordon, J. D. M.: Deep-sea demersal fish species richness in the Porcupine Seabight, NE Atlantic Ocean: global and regional patterns, Mar. Ecol.-Evol. Persp., 31, 247-260, 2010.
Priede, I. G., Godbold, J. A., Niedzielski, T., Collins, M. A., Bailey, D. M., Gordon, J. D. M., and Zuur, A. F.: A review of the spatial extent of fishery effects and species vulnerability of the deep-sea demersal fish assemblage of the Porcupine Seabight, Northeast Atlantic Ocean (ICES Sub-area VII), ICES J. Mar. Sci., 68, 281289, 2011.

R Development Core Team: R: a language and environment for statistical computing. Viennea, Austria, R Foundation for Statistical Computing, 2008.

Ramirez-Llodra, E., Tyler, P. A., Baker, M. C., Bergstad, O. A., Clark, M. R., Escobar, E., Levin, L. A., Menot, L., Rowden, A. A., Smith, C. R., and van Dover, C. L.: Man and the Last Great Wilderness: Human Impact on the Deep Sea, PLoS ONE 6, e22588, doi:10.1371/journal.pone.0022588, 2011.

Rose, K. A., Cowan Jr., J. H., Winemiller, W. O., Myers, R. A., and Hilborn, R.: Compensatory density dependence in fish populations: importance, controversy, understanding and prognosis, Fish Fish, 2, 293-327, 2001.

Watling, L. and Norse, E. A.: Disturbance of the seabed by mobile fishing gear: a comparison to forest clear cutting, Conserv. Biol., 12, 1180-1197, 1998.

Wood, S.: The mgcv Package v. 1.3-28, GAMs with GCV smoothness estimation and GAMM by REM L/PQL, http://cran. r-project.org/web/packages/mgcv/mgcv.pdf 2007.

Worm, B., Hilborn, R., Baum, J. K., Branch, T. A., Collie, J. S., Costello, C., Fogarty, M. J., Fulton, E. A., Hutchings, J. A., Jennings, S., Jensen, O. P., Lotze, H. K., Mace, P. M., McClanahan, T. R., Minto, C., Palumbi, S. R., Parma, A. M., Ricard, D., Rosenberg, A. A., Watson, R., and Zeller, D.: Rebuilding global fisheries, Science, 325, 578-585, 2009.

Zuur, A. F., Ieno, E. N., Walker, N. J., Saveliev, A. A., and Smith, G. M.: Mixed effects models and extensions in ecology with R, Springer Verlag, New York, LLC, 574 pp., 2009. 